\title{
WOJCIECH BOBROWICZ
}

Maria Curie-Skłodowska University in Lublin

ORCID: https://orcid.org/0000-0003-2270-1433

\section{THE CONCEPT OF NATIVE PHOTOGRAPHY BY JAN BUŁHAK IN THE CONTEXT OF MODERN AESTHETIC EDUCATION}

\begin{abstract}
This article is devoted to the concept of native photography created by Jan Bułhak in the 1930s and 1940s. This concept covers the idea of combining the aesthetics of landscape photography with the issue of patriotic education realized by the pictures of the homeland. The idea of native photography is transposed into modern times and the ubiquity of digital photography in new media, especially in social media.
\end{abstract}

Keywords: native photography, Jan Bułhak, patriotic education, social media

In 1951, the Ossoliński Publishing House of the National Institute in Wrocław published a book written by the senior of Polish photography, Jan Bułhak, titled Native Photography. The Issue about Socialization of Photography. In this article, I will try to compare some aspects of the thesis expressed by the author of the book, with the current trends in photography and the possibilities of using its achievements in enhancing the level of technical and aesthetic competencies for creators and viewers of photos - due to the widespread use of digital photography, almost all of them have access to modern mobile phones and social networks (primarily Facebook, Instagram, Pinterest, Flickr, etc.).

Bułhak was born in 1876 in Ostaszyn, in the region of Nowogródek (present-day Belarus). Since the beginning of the $20^{\text {th }}$ century, he dealt with photography, both as a photographer and as an educator. He was the creator of many outstanding photograms, which were exhibited at many places at home and abroad. Bułhak is an author of significant book titles aimed at popularizing photography and constituting a record of his reflections on artistic photography often based on 
his own art work. He was most often associated with the trend in photography referred to as pictorialism (Derczyński 1951, pp. v-ix; Jurecki 2004).

Pictorialism was an artistic movement that tried to make the photography an art by bringing it closer to traditional painting and graphic directions, seeking place for a new medium by exploiting - on the one hand - imperfections in the technique of photography (increasingly evolving towards mimetic reflection of reality), and on the other - by breaking away from mundane and triviality in favour of interpretation, which becomes much more important than the subject itself. It was particularly evident in the 1920s when the pictorialists took up the struggle with the realism and modernism of the emerging photographic art of these times (Rouillé 2007, pp. 292-293). Polish pictorialists, including Bułhak, were also involved in the fight. A. Rouillé defined the trend of pictorialism as follows:

(...) At the moment of pressing the shutter button the main enemy is sharpness, precision, excess detail and optical perfection; Enemy is centred on a lens that is alleged to have a false vision of what the human eye sees. So to approach the perception of the right eye, pictorialism wants to humanize the lens and reduce its mechanical dimension. In this way, different optical systems have been invented to connect lenses with elements whose function is to impair their properties. The most radical solution is to use an optical darkroom where the photography is obtained without use of a lens, by an archaic camera obscura - which is a hermetically sealed box with a hole of the size of a pin. (...) In order to obtain out of focus images (or not fully sharp ones), they were use a special "bad" corrective soft focus lenses, which - like the camera obscura - gave fuzzy, more poetic images (Rouillé 2007, pp. 297-299).

It is worth drawing attention to the current of pictorial photography that was clearly related to painting and graphic art. Bułhak himself claimed that "we are looking for the ideal in painting and example in graphics" (Jurecki 2004). The impressionism was at the foundation of pictorialism, even when it was somewhere forgotten in painting, replaced by the successive streams and artistic ideals of the turn of the $19^{\text {th }}$ and $20^{\text {th }}$ centuries. Representatives of the pictorial direction in photography for a long period remained on the same aesthetic positions at the end of the $19^{\text {th }}$ century:

(...) After a period in which Impressionism helps photography, then it itself - perceived as art - suggested the phenomenon of illumination, the illusory model of objects in Monet or Pissarro. Now photographers began to imitate the spraying of contours in the game of light. Pseudo-Impressionism has played a very important role in photography. Gradually, the supporters of this direction became epigones, unaware of where the models are imitated (Czartoryska 2002, p. 30). 
Despite the fact that Bułhak was treated (by many photographic historians) as an opponent of the new artistic trends characteristic of the interwar period, in his later period, he turned to at least partial aesthetic trends, such as abstraction (Jurecki 2004).

As the technology developed, photography became more realistic, almost technically perfect. This led to a kind of reaction aimed towards reaching the postmodern aesthetic old patterns and abandonment of too literal and realistic imaging of reality. At the end of the $20^{\text {th }}$ century, photographers tried to introduce their handwriting into their works, leading to the departure of the "identical, plural, serial, and reversal of the mechanics found to be too much. Thus the images gain material weight, and the process of acceleration and dematerialisation, which is subordinated to documentary images of the market, is becoming reversed" (Rouille 2007, p. 328). One of the activities of this type has become a very strong trend to return to the blurred and fuzzy images characteristic of pictorialism, all of these thanks to the use of the previously mentioned camera obscura (pinhole photography). As Rouillé has quoted already:

(...) The basic form of this aesthetic program - blurring (...) breaks long accepted equivalence between sharpness and technique. Breaking off the false precision of representation, blurry defines a position that is outside the area of utility; Photographic art is understood here as the inverse of the document, as a resistance to the flow of the photographic document (Rouillé 2007, p. 329).

Return to the past in photographic imagery of reality had already been predicted many years ago by another prominent Polish photographer and journalist J. Sunderland: "(...) on the way to the future - let us not forget the past: do not lose our experience and emotions and the aspirations, beauty and expression that, over the centuries, a great and ever-changing group of creators have taken away from man's fate" (Sunderland 1963, p. 64). These tendencies have clearly attempted to turn towards the work which - after the stage of avant-garde artistic experiments (abstract, conceptual, etc.) - was more about emotional expression and showing beauty - also openly drawing from aesthetics of pictorialism. The reason for this can be found in the fact that the avant-garde directions in art have become too difficult to receive and interpret for wide groups of audiences. From the point of view of modern directions in artistic photography we can even talk about a form of pastiche based on traditional conventions of landscape photography. For example, one can interpret the analysis of this type of pictures created by artists at the turn of the $20^{\text {th }}$ and $21^{\text {st }}$ centuries: 
(...) Photos of Scandinavian landscapes, made by Torbjørn Rødland (born 1970), show the sublime beauty and banality of landscape art. Through his composition (...) he fits into the conventions teaching how to take pictures of a beautiful landscape, also taking into account the misty sunrise and sunset as the classic forms of idyllic nature, which from landscape painting were transferred to professional landscape photography, and hence to our private holiday samples (Cotton 2010, p. 215).

It must be taken into account that the aesthetics of reception, and thus, the creation of photographs, is influenced by the huge number of photographs which we encounter every day. These will be both the above-mentioned private holiday photos and professionally produced photos, which we see in travel Internet sites and travel directory companies, etc.

One of the most important elements of creating photography - both artistic and for private use - is its communicativeness resulting from the viewer's understanding of the intentions of the photographer. In photography - differently than it is done in, e.g. painting - creating a visual message consists in choosing a slice of reality and presenting it in the form of a framed photo of the rectangle. As Sunderland wrote:

(...) The theme, seen in nature, has practically no borders. From all sides it goes from what is clearly seen to what it sees worse, from what matters, to what does not matter. The photographer (as well as the painter) takes a motive from the continuity of the visible world, captures it in geometric boundaries. By this selection (...) the result of the choice act of the photographer is attached, as well as his personality. The artist's spirit appears in the image (Sunderland 1963, pp. 3-4).

In this sense, each picture is our choice and reflection of ourselves: "Every human work can be interpreted as a self-portrait. From the photographs one can read about the author what he did not realize during the shooting - illuminate the sphere shadow in the psyche" (Frąckiewicz 2009, p. 212). On the other hand, when you look at pictures you should try to read the intention of the photographer, try to understand the purpose of the picture: "If vision is understanding, what can we grasp - looking? All of the countless pieces of information? Or only some of them?" (Arnheim 2013, p. 55).

B. Stiegler similarly wrote about the fact that modern-day photographers create songs that are a time, space, and information that must be readable both when we look at a photograph (about who, when, where and why a photograph was taken), and when we can (or should) understand the most accurate message we have made in our own image (Stiegler 2009, pp. 13-15). The author was referring directly to 
contemporary digital photography, noting that "digital photography is emerging as a new cultural technique that needs to be learned - like a writing - to understand it, but also to prevent the threat of indoctrination of images" (Stiegler 2009, p. 15).

At this point it is worthwhile to return to the character of Bułhak, who long ago pointed out the particular aspect of photography:

(...) After all, it is necessary not only to write with letters but also with shapes, and the ability to write with light must become common one day. Calligraphy is not required from every student, his writing may slant, as long as it is legible; the same case can be with the school of photography (Bułhak 1951, p. 33).

However, the author of Native Photography, in relation to landscape photography (in the most general sense) draws attention - and that is precisely the essence of his considerations - to aesthetic and compositional aspects: “(...) the documents of knowledge about the homeland should not be only recorded by the native photography but also pictured, simply said - in a charming, exciting, eye-catching and even emotional form" (Bułhak 1951, p. 47). Referring to other earlier photographic theory of homeland registration, “(...) Polish native photography should and can take care of the artistic composition to a far greater extent than it is recommended and done by some European countries which disdain the form instead of content" (Bułhak 1951, p. 20). When writing these words, Bułhak had in mind the famous Heimat fotografie in Germany (before or after World War II), from where, perhaps, he drew and interpreted his own assumptions of native photography.

Combining the aesthetic and documentary aspects of photography, Bułhak extended them in his native photography to socio-patriotic aspects: "a sightseeing photography extended by the socio-patriotic starting point, refined by higher artistic demands, a charming and convincing content layout" (Bułhak 1951, p. 21). In another place, he emphasized an aspect of combining aesthetic and social values:

(...) The native photography is the image presentation of the country, its naturalized area, showing of human activities and works in an accurate and expressive way, thanks to which such a presentation would contribute to deepening knowledge of one's home country and increasing joy and pride that national self-knowledge gives (Bułhak 1951, p. 57).

It is worth paying attention to the historical aspect of the views of Bułhak his texts on the issue of native photography were made partly in the period before 1939, and partly in the post-war years. They are the result of patriotic attitudes of part of the Polish society in the capitalist Poland of the interwar years, and, at 
the same time, they were updated in the second half of the 1940s, which became the foundation of a completely different aesthetics society, especially in the 1950s, as pointed out by K. Jurecki: "Paradoxically, ideas of pictorialism derived from the artist-noble world were one of the three mainstreams of socialist realism (1949-1955)" (Jurecki 2004). Apart from ideological and historical phenomena that underlie such a trade of understanding of the assumptions of the current of the native photography, it can be seen that this idea could easily have functioned in so diametrically different historical periods.

Generally speaking, since in the person and activity of Bułhak it was possible to combine such diverse values (both aesthetic and patriotic-social), it is perhaps also an opportunity (often ignoring rather pathetic formulations contained in native photography, which are not available to contemporary youth) without excessive ideologization, patriotic education and, at the same time, aesthetic education strongly rooted in our consciousness.

Despite the prevailing media image presenting a certain self-image-focused reality (such as the so-called selfie), it seems worth supporting those actions that encourage the inclusion of images not only of people in specific situations, but of more aesthetically altered places in which the person was staying. We often strive to emphasize that we have personally found ourselves in an interesting historical, cultural, natural, etc. place. So many people try to capture themselves in the foreground, and the image of the place is somewhere in the back, usually obscured by people in the foreground. The departure from this type of photography to the one that draws from the pictorial (and which is not controversial and seems to be acceptable to the vast majority of modern filmmakers and recipients) becomes an opportunity to change the axiology of modern media.

From the point of view of these considerations, it is not important how we will interpret regional, patriotic and cultural education - contemporary understanding of the nature of native photography can be adapted to a variety of interpretations and value systems. It is more important to pay attention to the fact that in times when due to the dynamics of social change, migration movements and political tensions, a significant number of people - our country's inhabitants - decide to spend leisure time in Poland, photographic documentation of visited places (performed in the creative and aesthetic way) can serve to develop a sense of shared responsibility for the appearance and aesthetics of our countryside. It seems that such a type of aesthetic and civic awareness may also affect other countries and build a cultural identity based on aesthetic values rather than xenophobia and confrontational attitudes. 


\title{
REFERENCES
}

Arnheim, R., 2013, Sztuka i percepcja wzrokowa. Psychologia twórczego oka. Łódź: Wydawnictwo Officyna.

Bułhak, J., 1951, Fotografia ojczysta. Rzecz o uspołecznieniu fotografii. Wrocław: Wydawnictwo Zakładu Narodowego im. Ossolińskich.

Cotton, C., 2010, Fotografia jako sztuka współczesna. Kraków: Towarzystwo Autorów i Wydawców Prac Naukowych UNIVERSITAS.

Czartoryska, U., 2002, Przygody plastyczne fotografii. Gdańsk: Wydawnictwo słowo/ obraz terytoria.

Derczyński, W., 1951, Wstęp. In: J. Bułhak, Fotografia ojczysta. Rzecz o uspołecznieniu fotografii. Wrocław: Wydawnictwo Zakładu Narodowego im. Ossolińskich.

Frąckiewicz, W., 2009, Świadome widzenie w fotografii. In: W. Bobrowicz (red.), Pedagogika i kultura. Pomiędzy teoria a praktyką. Lublin: Wydawnictwo Oficyna Wydawnicza VERBA.

Jurecki, K., 2004, Jan Buthak, http://culture.pl/pl/tworca/jan-bulhak [access: 26.08.2017]. Rouillé, A., 2007, Fotografia. Między dokumentem a sztuką współczesną. Kraków: Towarzystwo Autorów i Wydawców Prac Naukowych UNIVERSITAS.

Stiegler, B., 2009, Obrazy fotografii. Album metafor fotograficznych. Kraków: Towarzystwo Autorów i Wydawców Prac Naukowych UNIVERSITAS.

Sunderland, J., 1963, Estetyka fotografii krajobrazu. Warszawa: Wydawnictwa Artystyczne i Filmowe.

\author{
KONCEPCJA FOTOGRAFII OJCZYSTEJ JANA BUŁHAKA \\ W KONTEKŚCIE WSPÓŁCZESNEJ EDUKACJI ESTETYCZNEJ
}

\begin{abstract}
Abstrakt: Artykuł jest poświęcony koncepcji fotografii ojczystej, stworzonej przez Jana Bułhaka w latach 30. i 40. XX wieku. Koncepcja ta obejmuje pomysł połączenia estetyki fotografii krajobrazu z zagadnieniem wychowania patriotycznego, realizowanego przez zdjęcia ojczyzny. Pomysł fotografii ojczystej jest przeniesiony na czasy współczesne, uwzględnia wszechobecność fotografii cyfrowej w nowych mediach, szczególnie w mediach społecznościowych.
\end{abstract}

Słowa kluczowe: fotografia ojczysta, Jan Bułhak, wychowanie patriotyczne, media społecznościowe 